\title{
Lung Glandular Papilloma
}

National Cancer Institute

\section{Source}

National Cancer Institute. Lung Glandular Papilloma. NCI Thesaurus. Code C45601.

A benign papillary neoplasm that arises endobronchially. It is characterized by the presence of fibrovascular cores lined by columnar, cuboidal, and goblet cells. Patients usually present with signs and symptoms of bronchial obstruction. Complete resection is curative. 